\title{
Analisis Kestabilan Model Interaksi Predator-Prey dengan Fungsi Respon Monod-Haldane dan Perilaku Anti Pemangsa
}

\author{
Muhammad Bachtiar Gaib1, Wahdania At.Ja'a² \\ 1,2 Jurusan Matematika, Fakultas MIPA, Universitas Negeri Gorontalo, \\ Jl. Prof. Dr. Ing. B. J. Habibie, Tilongkabila, Kabupaten Bone Bolango, Gorontalo 96119, Indonesia
}

Email Korespondensi: m.tiargaib@gmail.com

\begin{abstract}
ABSTRAK
Artikel ini mengkaji model mangsa-pemangsa yang saling berkompetisi, dengan menggunakan fungsi respon Monod-Haldane dan perilaku anti pemangsa. Artikel ini membahas penentuan titik tetap, analisis kestabilan titik tetap dan simulasi numerik. Diperoleh tiga titik tetap yaitu $\mathrm{T}_{1}, \mathrm{~T}_{2}$ dan $\mathrm{T}_{3}$ dimana kestabilan titik tetap $\mathrm{T}_{1}$ selalu bersifat sadel, kestabilan titik tetap $\mathrm{T}_{2}$ dan $\mathrm{T}_{3}$ akan stabil jika memenuhi syarat parameter yang telah ditentukan. Terdapat dua kasus dalam titik tetap $\mathrm{T}_{3}$, dimana kasus pertama bersifat simpul stabil dan kasus kedua bersifat spiral stabil.
\end{abstract}

Kata Kunci:

Mangsa-Pemangsa; Monod-Haldane; Perilaku Anti Pemangsa

\section{Pendahuluan}

Dalam kehidupan setiap makhluk hidup tidak dapat terlepas dengan yang namanya interaksi. Interaksi merupakan suatu jenis tindakan yang terjadi ketika dua atau lebih objek mempengaruhi atau memiliki efek satu sama lain. Salah satu interaksi yang terjadi adalah interaksi antara mangsa dan pemangsa, yang sering disebut dengan interaksi prey-predator. Pada interaksi predator (pemangsa) mengkonsumsi prey (mangsa) agar dapat bertahan hidup dan fungsi predator terhadap prey adalah sebagai pengendali populasi prey [1]. Dinamika populasi adalah cabang ilmu kehidupan yang mempelajari perubahan jangka pendek dan jangka panjang dalam komposisi ukuran dan usia populasi, dan proses biologis serta lingkungan yang memengaruhi perubahan tersebut. Populasi yang dinamis berkaitan dengan cara populasi dipengaruhi oleh angka kelahiran dan kematian, dan oleh imigrasi dan emigrasi, dan mempelajari topik-topik seperti populasi yang menua atau penurunan populasi [2]. Model matematika merupakan representasi matematika yang dihasilkan dari pemodelan Matematika. Pemodelan Matematika merupakan suatu proses merepresentasikan dan menjelaskan permasalahan pada dunia nyata ke dalam pernyataan matematis [3].

Beberapa penelitian telah dilakukan mengenai model matematika khususnya pada interaksi predator-prey. Dalam [4] telah dikaji sistem predator-prey model leslie-gower dengan pemanenan secara konstan terhadap predator. Tujuan dari penelitian tersebut adalah memperlihatkan pengaruh dari pemanenan Predator terhadap dinamik dari sistem. Sistem memiliki paling banyak dua titik tetap yang memberikan dinamik berbeda disekitar titik tetap ketika pemanenannya divariasikan, dan memperlihatkan terjadinya 
bifurkasi Hopf pada sistem. Mortoja et al. dalam [5] mengemukakan bahwa Monod dan Haldane melakukan suatu penelitian terkait fungsi respon yang dikenal sebagai fungsi respon Holling tipe IV. Penelitian ini didasari bahwa interaksi predator-prey tidak selamanya monoton, yaitu saat dimana populasi mangsa meningkat maka populasi pemangsa akan menurun, dikarenakan adanya sifat bertahan atau defending dari mangsa. Berikut persamaan fungsi respon Monod-Haldane [6]:

$$
p(x)=\frac{a x}{n+\gamma x+x^{2}}
$$

Menurut Ruan dan Xiao, dalam [7], Sokol dan Howell [8] juga meneliti tentang predatorprey yang bersifat tidak monoton. Dalam penelitiannya, Sokol dan Howell menyatakan bahwa model fungsi respon Monod-Haldane yang mereka teliti secara signifikan lebih baik dan lebih sederhana. Berikut persamaannya:

$$
p(x)=\frac{a x}{n+x^{2}}
$$

Model predator-prey yang melibatkan perlakuan khusus terhadap predator juga telah dibahas pada [9][10]. Dalam artikel ini, kami akan memodifikasi model predator-prey yang ada dalam [1] dengan menggunakan model pertumbuhan logistik [11], fungsi respon Monod-Haldane dan perilaku anti pemangsa. Dari hasil modifikasi model, kami melakukan proses penentuan titik tetap, menganalisis kestabilan dari setiap titik tetap dan melakukan simulasi numerik pada salah satu titik tetap. Simulasi tersebut bertujuan untuk memperlihatkan bahwa model memiliki kestabilan yang bersifat simpul stabil dan spiral stabil.

\section{Model Matematika}

Model yang akan dibahas dalam artikel ini adalah model predator-prey dengan fungsi respon Monod-Haldane dengan perilaku anti pemangsa. Banyak populasi pada waktu $(t)$ terbagi menjadi 2 populasi yaitu populasi mangsa $(x)$ dan populasi pemangsa $(y)$. Asumsi-asumsi yang digunakan pada model predator-prey sebagai berikut:

1) Hanya terdapat masing-masing 1 jenis mangsa dan 1 jenis pemangsa dalam populasi.

2) Populasi mangsa diasumsikan bertumbuh secara logistik dan berkurang dengan adanya interaksi antar mangsa dan pemangsa yang tidak monoton.

3) Populasi pemangsa diasumsikan bertambah dengan adanya interaksi antar mangsa dan pemangsa yang tidak monoton, berkurang karena laju kematian alami dan berkurang karena adanya perilaku anti pemangsa dari populasi mangsa.

Berdasarkan asumsi diatas, diperoleh model persamaan berikut:

$$
\begin{gathered}
\dot{x}(t)=r x\left(1-\frac{x}{K}\right)-\frac{a x y}{x+n y^{2}} \\
\dot{y}(t)=\frac{b x y}{x+n y^{2}}-m y-\eta x y
\end{gathered}
$$

Keterangan parameter disajikan pada Tabel 1. 
Tabel 1. Parameter yang digunakan

\begin{tabular}{|c|c|c|}
\hline Simbol & Keterangan & Syarat \\
\hline$x$ & Banyaknya populasi mangsa & $x \geq 0$ \\
\hline$y$ & Banyaknya populasi pemangsa & $y \geq 0$ \\
\hline $\boldsymbol{r}$ & Laju pertumbuhan intrinsik mangsa & $r \geq 0$ \\
\hline $\boldsymbol{K}$ & Daya tampung lingkungan & $K \geq 0$ \\
\hline$a$ & $\begin{array}{l}\text { Koefisien interaksi antara mangsa dan pemangsa yang } \\
\text { berpengaruh terhadap laju pertumbuhan mangsa }\end{array}$ & $a \geq 0$ \\
\hline $\boldsymbol{b}$ & $\begin{array}{l}\text { Koefisien interaksi antara mangsa dan pemangsa yang } \\
\text { berpengaruh terhadap laju pertumbuhan pemangsa }\end{array}$ & $b \geq 0$ \\
\hline$m$ & Laju kematian alami pemangsa & $m \geq 0$ \\
\hline$n$ & Tingkat kejenuhan pemangsaan & $n \geq 0$ \\
\hline$\eta$ & Perilaku anti pemangsa & $\eta \geq 0$ \\
\hline
\end{tabular}

Dengan menggunakan bentuk simplifikasi, dimana $\beta=\frac{1}{x+n y^{2}}$, maka persamaan (1) menjadi:

$$
\begin{gathered}
\dot{x}(t)=r x\left(1-\frac{x}{K}\right)-\frac{a x y}{x+n y^{2}} \\
\dot{y}(t)=\frac{b x y}{x+n y^{2}}-m y-\eta x y
\end{gathered}
$$

Sesuai yang ada dalam [12], persamaan (2) ditransformasikan ke bentuk yang lebih sederhana dengan cara penondimensionalan model [13]. Skala parameter yang digunakan yaitu:

$$
x \rightarrow K x \quad y \rightarrow K y \quad t \rightarrow \frac{t}{K a}
$$

Sehingga persamaan (2) menjadi:

$$
\begin{aligned}
& \dot{x}(t)=\alpha x(1-x)-\beta x y \\
& \dot{y}(t)=\gamma x y-\delta y-\phi x y
\end{aligned}
$$

Dengan

$$
a=\frac{r}{K a} \quad \gamma=\frac{\beta b}{a} \quad \delta=\frac{m}{K a} \quad \phi=\frac{\eta}{a}
$$

Dalam persamaan (3), parameter $\alpha$ merepresentasikan tingkat pertumbuhan mangsa, parameter $\gamma$ merepresentasikan tingkat interaksi antara mangsa dan pemangsa, parameter $\delta$ merepresentasikan tingkat kematian pemangsa, serta parameter $\phi$ merepresentasikan tingkat perilaku anti pemangsa. 


\section{Hasil dan Pembahasan}

\subsection{Penentuan Titik Tetap}

Titik tetap persamaan (3) diperoleh dengan menyelesaikan persamaan $\dot{x}(t)=0$ dan $\dot{y}(t)=0$, sehingga diperoleh:

$$
\begin{aligned}
& \alpha x(1-x)-\beta x y=0 \\
& \gamma x y-\delta y-\phi x y=0
\end{aligned}
$$

Dengan menyelesaikan sistem persamaan (4), diperoleh 3 titik tetap, yaitu $T_{1}(0,0)$, $T_{2}(1,0)$ dan $T_{3}\left(x^{*}, y^{*}\right)$, dengan:

$$
\begin{gathered}
x^{*}=\frac{\delta}{\gamma-\phi} \\
y^{*}=\frac{\alpha(\gamma-\phi-\delta)}{\beta(\gamma-\phi)}
\end{gathered}
$$

Titik tetap $T_{3}\left(x^{*}, y^{*}\right)$ akan berada dikuadran pertama jika memenuhi:

$$
\begin{gathered}
x^{*}>0 \text { atau } \frac{\delta}{\gamma-\phi}>0 \\
y^{*}>0 \text { atau } \frac{\alpha(\gamma-\phi-\delta)}{\beta(\gamma-\phi)}>0
\end{gathered}
$$

Agar persamaan (5) dan (6) terpenuhi, maka:

$$
\delta>0 \text { dan } \gamma>\delta+\phi
$$

Pada saat $\gamma=\delta+\phi$, titik tetap $T_{3}$ akan menyatu dengan titik tetap $T_{2}$. Pada saat $\delta=0$, titik tetap $T_{3}$ akan menyatu dengan titik tetap $T_{1}$.

\subsection{Analisis Kestabilan Titik Tetap}

Dengan melakukan pelinearan [14] pada persamaan (4), diperoleh matriks jacobi sebagai berikut:

$$
J=\left(\begin{array}{cc}
\alpha-2 \alpha x-\beta y & -\beta x \\
\gamma y-\phi y & \gamma x-\delta-\phi x
\end{array}\right)
$$

Kita dapat menentukan kestabilan dari setiap titik tetap dengan menggunakan persamaan karakteristik [15] dan berdasarkan beberapa lemma berikut [16]:

Lemma 1. Persamaan (4) disekitar titik tetap $T_{1}$ selalu bersifat sadel.

Bukti:

Jika titik tetap $T_{1}(0,0)$ disubstitusikan ke dalam matriks jacobi (7) maka diperoleh:

$$
J_{(0,0)}=\left(\begin{array}{cc}
\alpha & 0 \\
0 & -\delta
\end{array}\right)
$$

Dengan menyelesaikan persamaan karakteristik $\operatorname{det}\left(J_{(0,0)}-\lambda I\right)=0$, diperoleh nilai eigen untuk matriks $J_{(0,0)}$, yaitu:

$$
\lambda_{1}=\alpha \text { dan } \lambda_{2}=-\delta
$$


Parameter $\alpha$ dan $\delta$ diasumsikan bernilai positif, maka $\lambda_{1}>0$ dan $\lambda_{2}<0$. Karena nilai-nilai eigen yang diperoleh berbeda tanda, maka titik tetap $T_{1}(0,0)$ memiliki kestabilan yang bersifat sadel.

Lemma 2. Persamaan (4) disekitar titik tetap $T_{2}$ akan stabil jika $\gamma<\delta+\phi$.

Bukti:

Jika titik tetap $T_{2}(1,0)$ disubstitusikan ke dalam matriks jacobi (7) maka diperoleh:

$$
J_{(1,0)}=\left(\begin{array}{cc}
-\alpha & -\beta \\
0 & \gamma-\delta-\phi
\end{array}\right)
$$

Dengan menyelesaikan persamaan karakteristik $\operatorname{det}\left(J_{(1,0)}-\lambda I\right)=0$, diperoleh nilai eigen untuk matriks $J_{(1,0)}$, yaitu:

$$
\lambda_{1}=-\alpha \text { dan } \lambda_{2}=\gamma-\delta-\phi
$$

Parameter $\alpha$ diasumsikan bernilai positif sehingga $\lambda_{1}<0$. Apabila $\gamma<\delta+\phi$, maka diperoleh nilai $\lambda_{2}<0$. Sehingga titik tetap $T_{2}$ bersifat stabil

Lemma 3. Persamaan (4) disekitar titik tetap $T_{3}$ akan stabil jika $A<0$ dan $B>0$.

Bukti:

Jika titik tetap $T_{3}\left(x^{*}, y^{*}\right)$ disubstitusikan ke dalam matriks jacobi (7) maka diperoleh:

$$
J_{\left(x^{*}, y^{*}\right)}=\left(\begin{array}{ll}
M_{11} & M_{12} \\
M_{21} & M_{22}
\end{array}\right)
$$

Dimana:

$$
M_{11}=-\frac{\alpha \delta}{\gamma-\phi} ; M_{12}=-\frac{\beta \delta}{\gamma-\phi} ; M_{21}=\frac{\alpha(\gamma-\phi-\delta)}{\beta} ; M_{22}=0
$$

Nilai eigen diperoleh dengan menyelesaikan persamaan karakteristik $\operatorname{det}\left(J_{\left(x^{*}, y^{*}\right)}-\lambda I\right)=0$ yaitu:

$$
\begin{gathered}
\left|\begin{array}{cc}
M_{11}-\lambda & M_{12} \\
M_{21} & M_{22}-\lambda
\end{array}\right|=0 \\
\lambda^{2}-\left(M_{11}+M_{22}\right) \lambda+M_{11} M_{22}-M_{12} M_{21}=0 \\
\lambda^{2}-A \lambda+B=0
\end{gathered}
$$

Sehingga

$$
\lambda_{1,2}=\frac{A \pm \sqrt{A^{2}-4 B}}{2}
$$

Dengan

$$
A=-\frac{\alpha \delta}{\gamma-\phi} ; \quad B=\frac{\delta \alpha(\gamma-\phi-\delta)}{\gamma-\phi}
$$

Karena parameter $\alpha, \delta$ diasumsikan bernilai positif maka harus memenuhi $A<0$. Jika $B>0$, diperoleh $\delta<\gamma-\phi$. Hal ini sesuai dengan syarat (21), maka titik tetap $T_{3}\left(x^{*}, y^{*}\right)$ bersifat stabil. 


\subsection{Simulasi Numerik}

Dinamika populasi mangsa-pemangsa dapat ditunjukkan melalui kurva bidang fase dan bidang solusi yang menggambarkan populasi mangsa dan pemangsa pada kurun waktu tertentu. Dengan ini, masing-masing variabel dan parameter membutuhkan suatu nilai awal untuk proses komputasi. Proses komputasi pada simulasi ini dilakukan dengan bantuan software Wolfram Mathematica 11.3 dan software Maple 18.

Diasumsikan nilai parameter yang bernilai tetap untuk simulasi ini adalah $\alpha=0.1, \delta=$ 0.01 dan $\phi=0.2$. Parameter $\beta$ dan $\gamma$ merupakan parameter kontrol pada sistem yang nilainya tidak selalu tetap. Parameter yang digunakan dalam simulasi ini dapat dilihat pada Tabel 2.

Tabel 2. Pemilihan Nilai Parameter

\begin{tabular}{ccc}
\hline Parameter & Kasus 1 & Kasus 2 \\
\hline $\boldsymbol{\alpha}$ & 0.1 & 0.1 \\
$\boldsymbol{\delta}$ & 0.01 & 0.01 \\
$\boldsymbol{\phi}$ & 0.2 & 0.2 \\
$\boldsymbol{\beta}$ & 0.22 & 0.23 \\
$\boldsymbol{\gamma}$ & 0.22 & 0.23 \\
\hline $\boldsymbol{T}_{\mathbf{3}}$ & Simpul Stabil & Spiral Stabil \\
\hline
\end{tabular}

\subsubsection{Dinamika Populasi Predator-Prey Kasus 1}

Pada kasus ini, parameter 314amper314 yang digunakan yaitu $\beta=\gamma=0.22$, serta nilai awal $x(0)=0.3$ dan $y(0)=0.5$. Titik tetap $T_{3}$ yang diperoleh pada kasus ini adalah $T_{3}(0.5,0.227273)$. Nilai eigen yang diperoleh adalah $\lambda_{1}=-0.0361803$ dan $\lambda_{2}=$ -0.0138197 , sehingga kestabilan titik tetap $T_{3}$ bersifat simpul stabil.

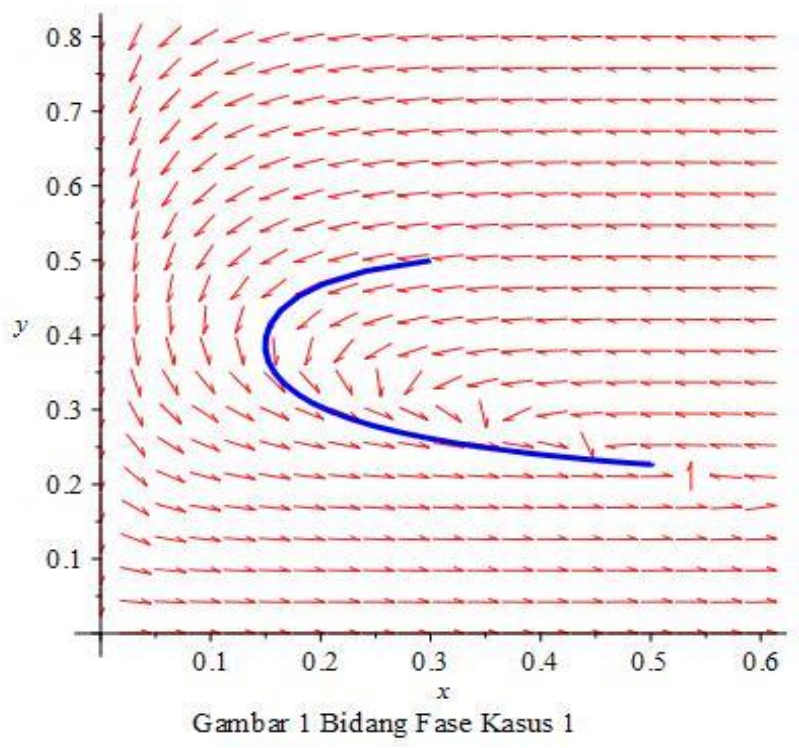


Pada Gambar 1, diberikan ilustrasi bidang fase disekitar titik tetap dimana kedua populasi stabil menuju titik tetap $T_{3}$. Diperlihatkan bahwa jenis kestabilan titik tetapnya adalah stabil.

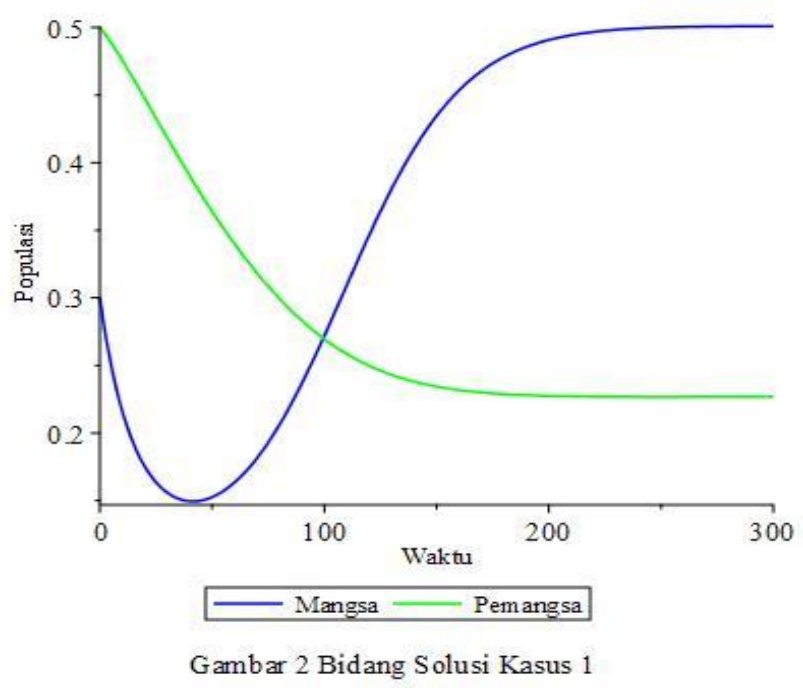

Pada Gambar 2, diperlihatkan bahwa di awal waktu kedua populasi mengalami penurunan jumlah, dimana populasi mangsa 315amper mengalami kepunahan dikarenakan sifat defending yang dimiliki. Setelah itu, populasi pemangsa mengalami penurunan yang mengakibatkan populasi mangsa mengalami pertumbuhan. Pada akhirnya kedua populasi tersebut stabil menuju ke satu nilai.

\subsubsection{Dinamika Populasi Predator-Prey Kasus 2}

Pada kasus ini, parameter kontrol yang digunakan yaitu $\beta=\gamma=0.23$, serta nilai awal $x(0)=$ 0.2 dan $y(0)=0.6$. Titik tetap $T_{3}$ yang diperoleh pada kasus ini adalah $T_{3}(0.333333,0.289855)$. Nilai eigen yang diperoleh adalah $\lambda_{1}=-0.0166667+0.0197203 \boldsymbol{i}$ dan $\lambda_{2}=-0.0166667+0.0197203 \boldsymbol{i}$, sehingga kestabilan titik tetap $T_{3}$ bersifat spiral stabil.

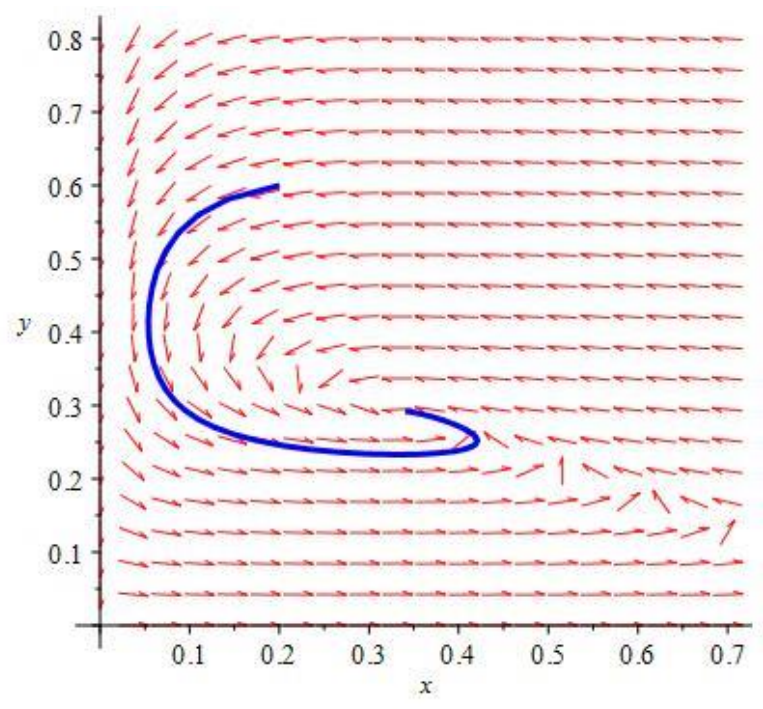

Gambar 3 Bidang F ase Kasus 2 
Pada Gambar 3, diberikan ilustrasi bidang fase disekitar titik tetap dimana kedua populasi stabil menuju titik tetap $T_{3}$. Diperlihatkan bahwa jenis kestabilan titik tetapnya adalah stabil.

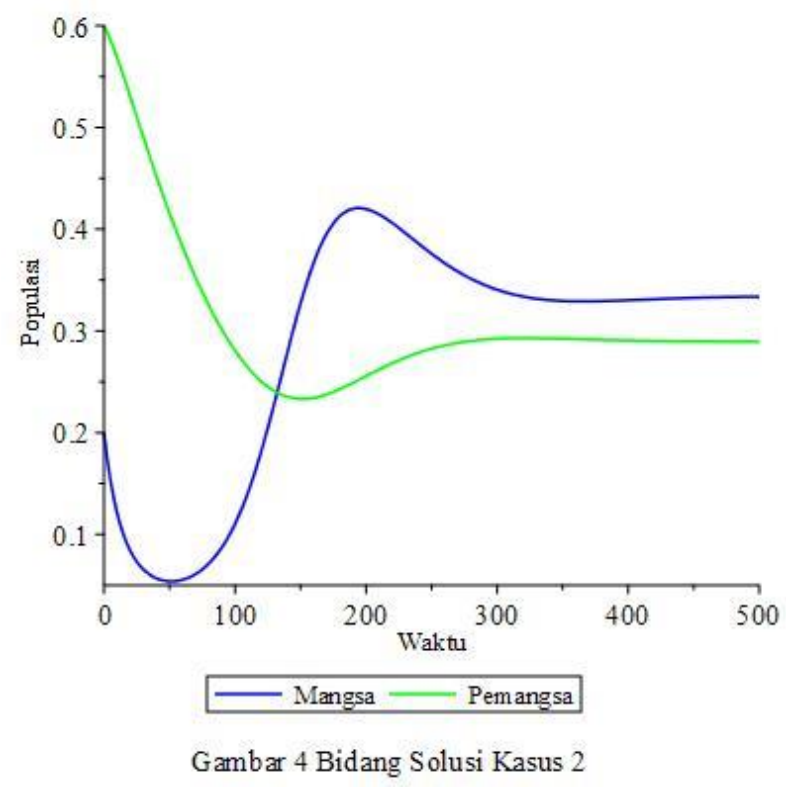

Pada Gambar 4, diperlihatkan bahwa di awal waktu kedua populasi mengalami penurunan jumlah, dimana populasi mangsa hampir mengalami kepunahan pada interval waktu $0-50$ hari dikarenakan sifat defending yang dimiliki sedangkan populasi pemangsa mengalami penurunan jumlah pada interval waktu $0-150$ hari. Kemudian pada interval waktu $50-$ 200 hari populasi mengalami peningkatan jumlah populasi yang signifikan sedangkan pada interval waktu 150 - 300 hari populasi pemangsa juga mengalami peningkatan dikarenakan jumlah populasi mangsa meningkat sehingga menimbulkan interaksi antar mangsa dan pemangsa. Oleh sebab itu, pada interval waktu 200 - 300 hari populasi mangsa mengalami penurunan dikarenakan interaksi tersebut. Pada akhirnya kedua populasi tersebut stabil menuju ke satu nilai.

\section{Kesimpulan}

Dari hasil analisis model, diperoleh tiga titik tetap, yaitu $T_{1}, T_{2}$ dan $T_{3}$. Kestabilan titik tetap $T_{1}$ selalu bersifat sadel. Kestabilan titik tetap $T_{2}$ bergantung pada nilai parameter yang dipilih yang menyebabkan kestabilannya bersifat sadel jika $\gamma>\delta+\phi$ dan bersifat stabil jika $\gamma<\delta+\phi$. Kestabilan titik tetap $T_{3}$ juga akan stabil jika memenuhi syarat $A<$ 0 dan $\delta<\gamma-\phi$.

Dinamika populasi mangsa-pemangsa model ini terbagi atas 2 kasus, dimana parameter $\beta$ dan $\gamma$ merupakan parameter kontrol pada sistem yang nilainya tidak selalu tetap. Pada kasus 1 , kestabilan titik tetap $T_{3}$ bersifat simpul stabil dimana nilai parameter kontrolnya yaitu $\beta=\gamma=0.22$. Sedangkan pada kasus 2 , kestabilan titik tetap $T_{3}$ bersifat spiral stabil dimana nilai parameter kontrolnya yaitu $\beta=\gamma=0.23$. Pada kedua kasus ini, hampir terjadi kepunahan pada populasi mangsa yang disebabkan oleh perilaku anti pemangsa dan sifat defending dari mangsa. 


\section{Referensi}

[1] Abadi., Saadah, S., \& Savitri, D. (2019). Model Interaksi Mangsa Pemangsa Dengan Fungsi Respon Rasio Dependent Holling Tipe II dan Perilaku Anti Pemangsa. MATHunesa Jurnal Ilmiah Matematika, (7)2, 6-9.

[2] Turchin, P. B. (2003). Complex Population Dynamics: A Theorical/Empirical Synthesis. New Jersey: Princeton University Press.

[3] Widowati \& Sutimin. (2007). Buku Ajar Pemodelan Matematika. Semarang: UNDIP Press.

[4] Panigoro, H. S. (2014). Analisis Dinamik Sistem Predator-Prey Model LeslieGower dengan Pemanenan Secara Konstan Terhadap Predator. Euler, 2(1), 1-12.

[5] Mortoja, S. G., Panja, P., \& Mondal, S. K. (2018). Dynamics of a Predator-Prey Model with Stage-Structure on Both Species and Anti-Predator Behavior. Informatics in Medicine Unlocked, 10, 50-57. doi:https:// doi.org/10.1016/j.imu.2017.12.004.

[6] Agarwal, M. \& Pathak, R. (2012). Harvesting and Hopf Bifurcation in a PredatorPrey Model with Holling Type IV Functional Response. International Journal of Mathematics and Soft Computing, (2)1, 83-92.

[7] Ruan, S. \& Xiao, D. (2001). Global Analysis in a Predator-Prey System with Nonmonotonic Functional Response. SIAM J Appl Math, 61(4): 1445-1472.

[8] Sokol, W. \& Howell, J. A. (1980). Kinetics of Phenol Oxidation by Washed Cells, Biotechnol. Bio-eng., 23(1980), 2039-2049.

[9] S. H. Arsyad, R. Resmawan, and N. Achmad, "Analisis Model Predator-Prey Leslie-Gower dengan Pemberian Racun Pada Predator," J. Ris. dan Apl. Mat., vol. 4, no. 1, pp. 1-16, 2020.

[10] N. Hasan, R. Resmawan, and E. Rahmi, "Analisis Kestabilan Model EkoEpidemiologi dengan Pemanenan Konstan pada Predator," J. Mat. Stat. dan Komputasi, vol. 16, no. 2, pp. 121-142, Dec. 2020.

[11] Logan, J. D. (2010). First Course in Differential Equations (Second Edition). New York: Springer-Verlag.

[12] Gaib, M. B. (2013). Bifurkasi Hopf Pada Model Mangsa-Pemangsa Holling-Tanner Tipe II. [Skripsi]. Bogor(ID): Institut Pertanian Bogor.

[13] Strogatz, S. H. (1994). Nonlinear Dynamics and Chaos with Application to Physics, Biology, Chemistry, and Engineering. Massachusets (US): Addison-Wesley Publishing Company.

[14] Hale, J. K. \& Kocak, H. (1991). Dynamic and Bifurcation. New York: Springer-Verlag.

[15] Anton, H. \& Rorres, C. (1987). Aljabar Linear Elementer. Jakarta: Erlangga.

[16] Diska, M. (2018). Analisis Kestabilan Model Mangsa-Pemangsa Dengan Struktur Umur Pemangsa dan Fungsi Respon Monod-Haldane. [Skripsi]. Bogor(ID): Institut Pertanian Bogor. 